
ВІННИЦЬКИЙ НАЦІОНАЛЬНИЙ МЕДИЧНИЙ УНІВЕРСИТЕТ ІМЕНІ М. І. ПИРОГОВА

\title{
ДОСЛІДЖЕННЯ ВУГЛЕВОДІВ КОРЕНЕВИЩ І КОРЕНІВ ТА ТРАВИ РОДОВИКА ЛІКАРСЬКОГО (SANGUISORBA OFFICINALIS L.)
}

Вступ. Родовик лікарський (Sanguisorba officinalis L.) - багаторічна рослина родини розові (Rosaceae). Для медичних цілей використовують траву, яку заготовляють під час цвітіння, та кореневища і корені, які заготовляють восени, коли надземна частина починає в'янути. Родовик лікарський здавна застосовують у народній медицині як в'яжучий, протизапальний, болетамувальний і кровоспинний засіб. Доцільними $\epsilon$ дослідження кількісного вмісту та якісного складу вуглеводів кореневищ і коренів родовика лікарського та його трави, оскільки вуглеводи, крім важливого фрункціонального значення і специфрічної фрармакологічної активності, впливають на розвиток сумарного фрармакологічного ефекту препаратів, отриманих із рослинної сировини.

Мета дослідження - визначити, виділити і вивчити полісахариди підземних органів та трави родовика лікарського, а також проаналізувати їх моноцукровий склад.

Методи дослідження. Об'єктами для досліджень були кореневища і корені та трава родовика лікарського, заготовлені у 2014-2016 рр. на дослідних ділянках НОК “Червона калина" Тернопільського державного медичного університету імені І. Я. Горбачевського (с. Дружба Тернопільського району). Для проведення якісних реакцій на полісахариди готували водні витяжки з лікарської рослинної сировини. Кількісний вміст водорозчинних полісахаридів та пектинових речовин у досліджуваній сировині визначали гравіметричним методом. Якісний склад та кількісний вміст моноцукрів і сахарози досліджували методом газової хромато-мас-спектрометрії.

Результати й обговорення. Результати досліджень підтвердили наявність полісахаридів у водних витяжках з трави і підземних органів родовика лікарського. Встановлено, що у траві рослини вищий вміст пектинових речовин (8,75 \%), у кореневищах і коренях - водорозчинних полісахаридів (7,35 \%). У складі полісахаридних комплексів кореневищ і коренів родовика лікарського встановлено наявність та визначено кількісний вміст 15 моноцукрів після кислотного гідролізу, з яких ідентифріковано 8; вільних цукрів виявлено 16, ідентифріковано 7 компонентів - арабінозу, манозу, глюкозу, фрруктозу, інозитол, манітол і дицукор сахарозу. В складі полісахаридних комплексів трави рослини встановлено наявність та визначено кількісний вміст 16 моноцукрів після кислотного гідролізу, з яких ідентифріковано 9; вільних цукрів виявлено 12, ідентиоріковано 5 компонентів - манозу, глюкозу, фрруктозу, інозитол і дицукор сахарозу. Серед моноцукрів у досліджуваній сировині домінувала глюкоза, яка утворилася після кислотного гідролізу, найвищий ії вміст спостерігали у траві родовика (29,96 мг/2). Глюкози у вільному стані більше в кореневищах і коренях рослини (18,55 м2/2). Вміст сахарози в досліджуваних об'єктах був майже однаковий і становив у кореневищах і коренях 48,23 мг/2, у траві - 49,87 мг/2.

Висновки. Аналіз результатів проведених досліджень свідчить про високий вміст водорозчинних полісахаридів у кореневищах і коренях та пектинових речовин у траві родовика лікарського. Склад цукрів кореневищ і коренів, а також трави рослини характеризується переважанням у кількісному співвідношенні моноцукру глюкози та дицукру сахарози. Досліджуваний вид є перспективним для використання в медичній практиці й вимагає розширеного фрітохімічного і фрармакологічного аналізу.

КЛЮЧОВІ СЛОВА: родовик лікарський; трава; кореневища і корені; полісахариди; цукри.

ВСТУП. Родовик лікарський (Sanguisorba officinalis L.) - багаторічна рослина родини розові (Rosaceae) з коротким здерев'янілим кореневищем та темно-коричневими товстими і довгими додатковими коренями. Стебла прямостоячі, ребристі, вгорі розгалужені. Листки непарноперисті, з яйцеподібними листочками; (с С. М. Марчишин, В. В. Кудря, І. С. Дахим, О. В. Зарічанська, 2018. прикореневі зібрані в розетку. Квітки темно-червоні або чорно-пурпурові, зібрані в яйцеподібні суцвіття. Для медичних цілей використовують траву, яку заготовляють під час цвітіння, та кореневища і корені, які заготовляють восени, коли надземна частина починає в'янути. Родовик лікарський здавна застосовують у народній медицині як в'яжучий, протизапальний, болетамувальний і кровоспинний засіб $[1,2]$. 
Відомо, що кореневища і корені рослин накопичують речовини первинного синтезу вуглеводи. Дослідження кількісного вмісту та якісного складу вуглеводів кореневищ і коренів родовика лікарського є доцільними у зв'язку 3 тим, що вуглеводи, крім важливого фрункціонального значення і специфрічної фрармакологічної активності, також впливають на розвиток сумарного фрармакологічного ефекту препаратів, отриманих із рослинної сировини [3]. Трава родовика лікарського як недостатньо вивчена рослинна сировина також $€$ перспективним об'єктом дослідження, в тому числі й вуглеводного складу.

Мета дослідження - визначити, виділити і вивчити полісахариди підземних органів та трави родовика лікарського, а також проаналізувати їх моноцукровий склад.

МЕТОДИ ДОСЛІДЖЕННЯ. Об'єктами ДЛЯ досліджень були кореневища і корені та трава родовика лікарського, заготовлені у 20142016 рр. на дослідних ділянках НОК “Червона калина" Тернопільського державного медичного університету імені І. Я. Горбачевського (с. Дружба Тернопільського району). Траву заготовляли в період цвітіння рослини, кореневища і корені після відмирання надземної її частини. Сировину сушили в тепло-конвекційній сушарці при температурі $40{ }^{\circ} \mathrm{C}$; кореневища і корені попередньо швидко промивали в проточній холодній воді й розрізали поздовжньо.

Для проведення якісних реакцій на полісахариди (ПС) готували водні витяжки з лікарської рослинної сировини. Для цього 30 г подрібненої сухої сировини заливали 250 мл гарячої води очищеної P і настоювали протягом доби. Водні витяжки фрільтрували, а сировину заливали 100 мл гарячої води очищеної Р. Операцію повторювали 3-5 разів. Водні витяжки об'єднували і випарювали до 15 мл. Одержану витяжку використовували для виявлення ПС.

До 10 мл витяжки приливали 30 мл $95 \%$ етанолу Р. Поява плаваючих пластинчастих згустків, що при відстоюванні випадали в осад, свідчила про наявність у досліджуваній сировині ПС. Осад відфрільтровували і проводили реакцію на виявлення відновлюваних (нейтральних) цукрів.

Осад переносили у пробірку, доливали 5 мл розведеної кислоти хлоридної і кип'ятили протягом 30 хв. До охолодженого гідролізату додавали 10 мл реактиву Фелінга і знову кип'ятили. Поява цеглисто-червоного осаду свідчила про наявність відновлюваних цукрів [4].

Кількісний вміст водорозчинних полісахаридів (ВРПС) та пектинових речовин (ПР) у дослі- джуваній сировині визначали гравіметричним методом [5, 6].

Якісний склад та кількісний вміст моноцукрів і сахарози досліджували методом газової хромато-мас-спектрометрії (ГХ/МС). Метод оснований на екстракції вільних моноцукрів та отриманні ацетатів їх альдонітрильних похідних 3 подальшим аналізом методом ГХ/MC [7, 8]. Хроматографрічне розділення проводили на газовій хромато-мас-спектрометричній системі Agilent 6890N/5973inert (Agilent technologies, США). Використовували колонку капілярну HP-5ms (30 m×0,25 mm×0,25 mkm, Agilent technologies, США). Ідентифрікацію здійснювали за часом утримання стандартів моноцукрів та 3 використанням бібліотеки мас-спектрів NIST 02.

Пробопідготовка рослинної сировини полягала в екстракції загальних та вільних цукрів за різних умов.

Кількісний аналіз проводили шляхом додавання розчину внутрішнього стандарту в досліджувані проби. Як внутрішній стандарт використовували розчин сорбітолу [9].

Масу моноцукру і сахарози (мг) на 1 кг сировини розраховували за фрормулою:

$$
\mathrm{X}=\frac{\mathrm{Sx} \cdot \mathrm{MBн} . \mathrm{CT} \cdot \mathbf{1 0 0 0}}{\mathrm{SBH} . \mathrm{CT} \cdot \mathrm{m}},
$$

де Sx - площа піку шуканого моноцукру;

Мвн.ст. - маса внутрішнього стандарту на пробу;

Sвн.ст. - площа піку внутрішнього стандарту; m - наважка препарату.

РЕЗУЛЬТАТИЙ ОБГОВОРЕННЯ. РеЗУЛЬТаТИ досліджень підтвердили наявність ПС у водних витяжках з трави і підземних органів родовика лікарського:

- 395 \% етанолом Р спостерігали появу пластинчастих згустків, які з часом випадали в осад;

- з реактивом Фелінга після кислотного гідролізу відзначали появу цегляно-червоного осаду, що свідчило про наявність нейтральних (відновлюваних) цукрів.

Досліджено полісахаридні комплекси трави та кореневищ і коренів родовика лікарського, встановлено кількісний вміст водорозчинних полісахаридів та пектинових речовин. Одержані ВРПС - це аморфні порошки світло-коричневого кольору, які розчиняються у воді (рН водних розчинів перебуває в межах 5-6, розчини опалесціюють), водних розчинах лугів та кислот і не розчиняються в органічних розчинниках. Полісахариди дають позитивний результат при реакції осадження 96 \% етанолом $\mathrm{P}$ та з реактивом Фелінга після проведення кислотного гідролізу. Одержані ПР - це аморфні порошки коричневого кольору, в очищеній воді Р розчиняються 3 
утворенням колоїдних в'язких мутних розчинів, рН яких становить 4-5. Водні розчини ПР осаджуються 1 \% розчином алюмінію сульфату 3 утворенням пектатів.

Результати кількісного визначення ВРПС і ПР родовика лікарського наведено в таблиці 1.

Результати досліджень свідчать про те, що у траві родовика лікарського вищий вміст ПР $(8,75 \%)$, у кореневищах і коренях - ВРПС (7,35\%).

Результати визначення цукрів у досліджуваній рослинній сировині представлено в таблиці 2 та на рисунках 1-4.

У складі полісахаридних комплексів кореневищ і коренів родовика лікарського встановлено наявність та визначено кількісний вміст 15 моноцукрів після кислотного гідролізу, з яких ідентифріковано 8 (рис. 1); вільних цукрів виявлено 16, ідентифріковано 7 компонентів - арабінозу, манозу, глюкозу, фрруктозу, інозитол, манітол і дицукор сахарозу (рис. 2).

У складі полісахаридних комплексів трави рослини встановлено наявність та визначено кількісний вміст 16 моноцукрів після кислотного гідролізу, з яких ідентифріковано 9 (рис. 3); вільних цукрів виявлено 12, ідентиоріковано 5 компонентів - манозу, глюкозу, фрруктозу, інозитол і дицукор сахарозу (рис. 4). Окрім глюкози, в обох досліджуваних об'єктах спостерігали наявність манози та інозитолу.

Таблиця 1 - Кількісний вміст водорозчинних полісахаридів і пектинових речовин у сировині родовика лікарського

\begin{tabular}{||l|c|c|c|c|}
\hline \multicolumn{1}{|c|}{ Сировина } & ПС & Маса сировини, г & Вміст ПС, г & Вихід ПС, \% \\
\hline \multirow{2}{*}{$\begin{array}{l}\text { Кореневища } \\
\text { і корені }\end{array}$} & ВРПС & 20,5603 & 1,5173 & 7,35 \\
\cline { 2 - 5 } & ПР & 17,5524 & 0,9846 & 5,61 \\
\cline { 2 - 5 } & ВРПС & 9,200 & 1,205 & 6,09 \\
\hline
\end{tabular}

Таблиця 2 - Якісний склад і кількісний вміст цукрів у сировині родовика лікарського

\begin{tabular}{|c|c|c|c|c|}
\hline \multirow{3}{*}{ Цукри } & \multicolumn{4}{|c|}{ Вміст у рослинній сировині, мг/г } \\
\hline & \multicolumn{2}{|c|}{ кореневища і корені } & \multicolumn{2}{|c|}{ трава } \\
\hline & цукри після гідролізу & вільні цукри & цукри після гідролізу & вільні цукри \\
\hline Рамноза & 0,23 & - & 0,89 & - \\
\hline Арабіноза & 0,92 & 0,55 & 0,67 & - \\
\hline Глюкоза & 25,65 & 18,55 & 29,96 & 15,85 \\
\hline Фруктоза & - & 5,27 & - & 1,81 \\
\hline Галактоза & 0,84 & - & 4,21 & - \\
\hline Маноза & 0,48 & 1,34 & 0,69 & 7,24 \\
\hline Інозитол & 0,34 & 0,32 & 4,68 & 4,33 \\
\hline Манітол & 0,23 & 0,33 & 0,29 & - \\
\hline Дулцитол & 0,15 & - & 0,14 & - \\
\hline Сахароза & - & 48,23 & - & 49,87 \\
\hline Фукоза & - & - & 0,08 & - \\
\hline
\end{tabular}

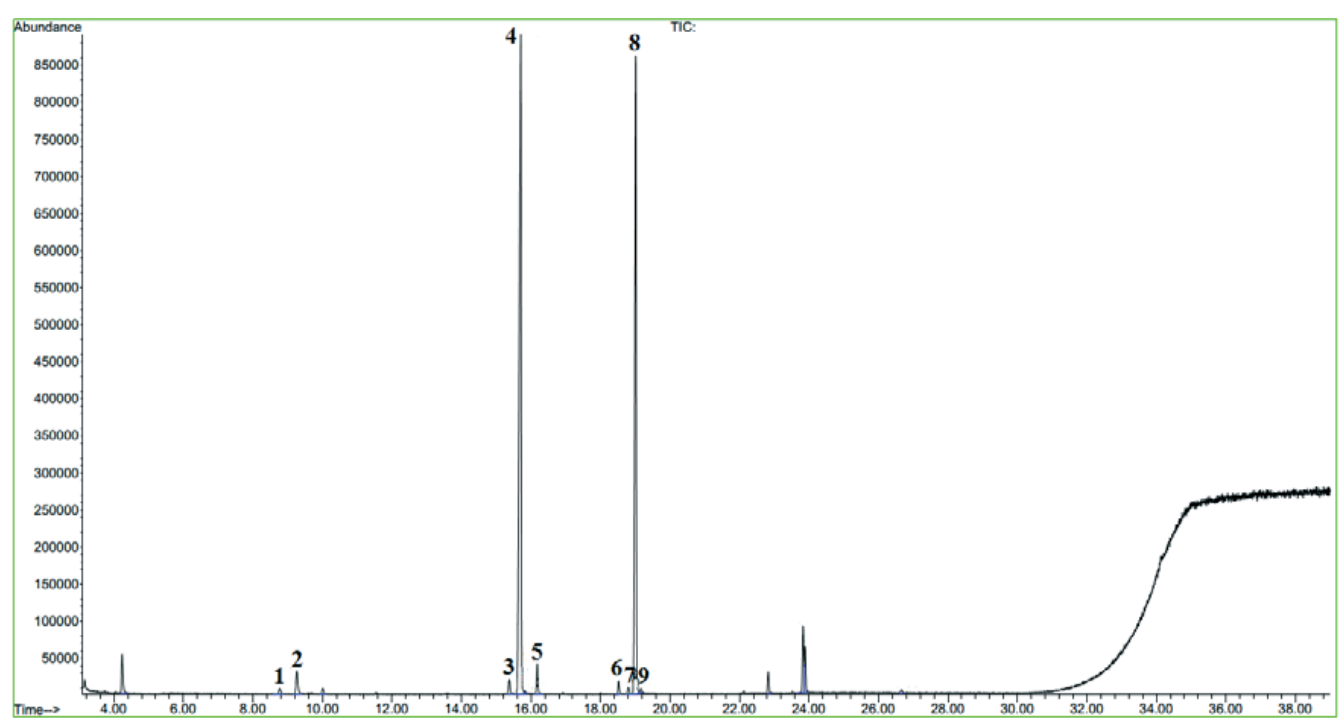

Рис. 1. Хроматограма моноцукрів після кислотного гідролізу полісахаридів кореневищ і коренів родовика: 1 - рамноза; 2 - арабіноза; 3 - маноза; 4 - глюкоза; 5 - галактоза; 6 - інозитол; 7 - манітол; 8 - сорбітол; 9 - дульцитол. 


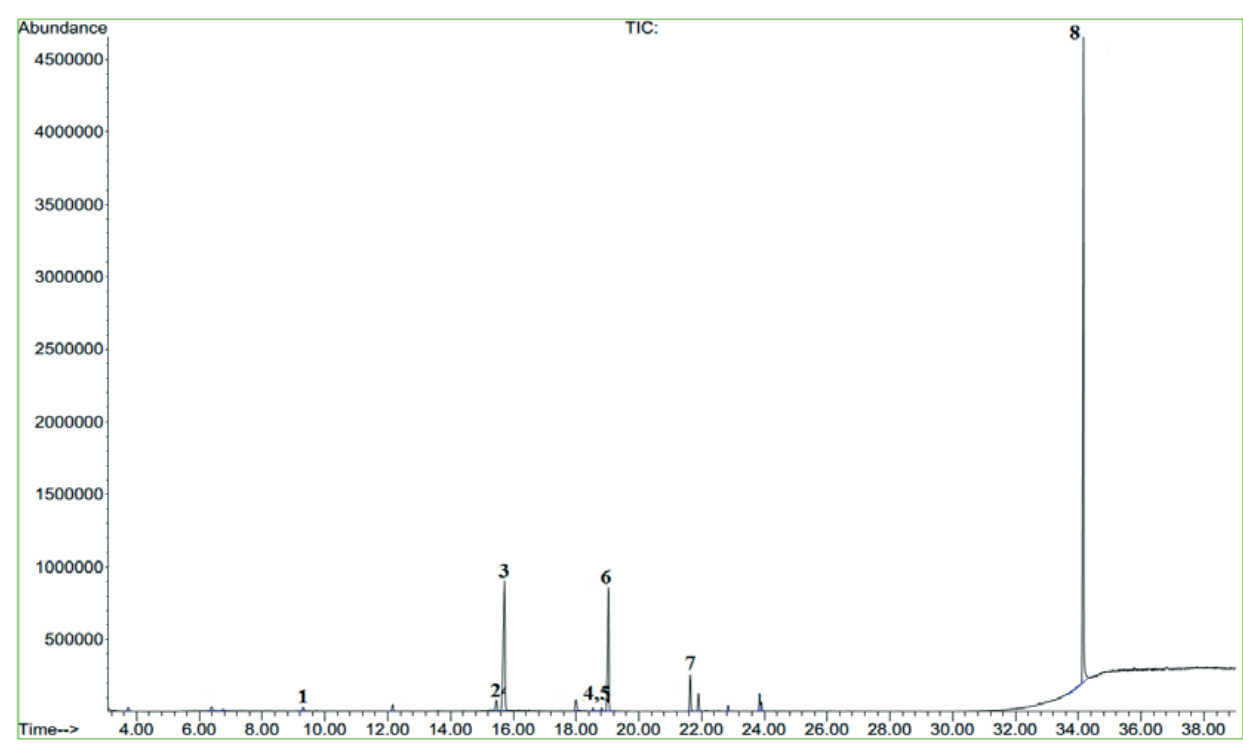

Рис. 2. Хроматограма вільних моноцукрів та сахарози кореневищ і коренів родовика: 1 - арабіноза; 2 - маноза; 3 глюкоза; 4 - інозитол; 5 - манітол; 6 - сорбітол; 7 - фрруктоза; 8 - сахароза.

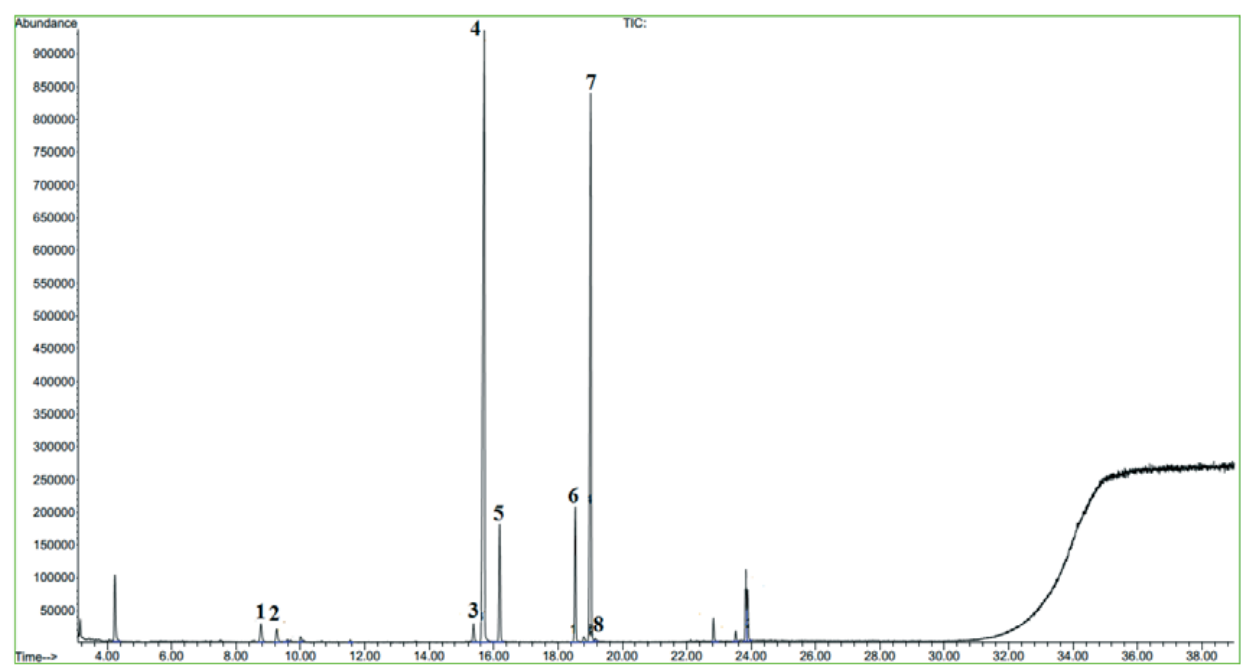

Рис. 3. Хроматограма моноцукрів після кислотного гідролізу полісахаридів трави родовика: 1 - рамноза; 2 - арабіноза; 3 - маноза; 4 - глюкоза; 5 - галактоза; 6 - інозитол; 7 - манітол; 8 - дульцитол.

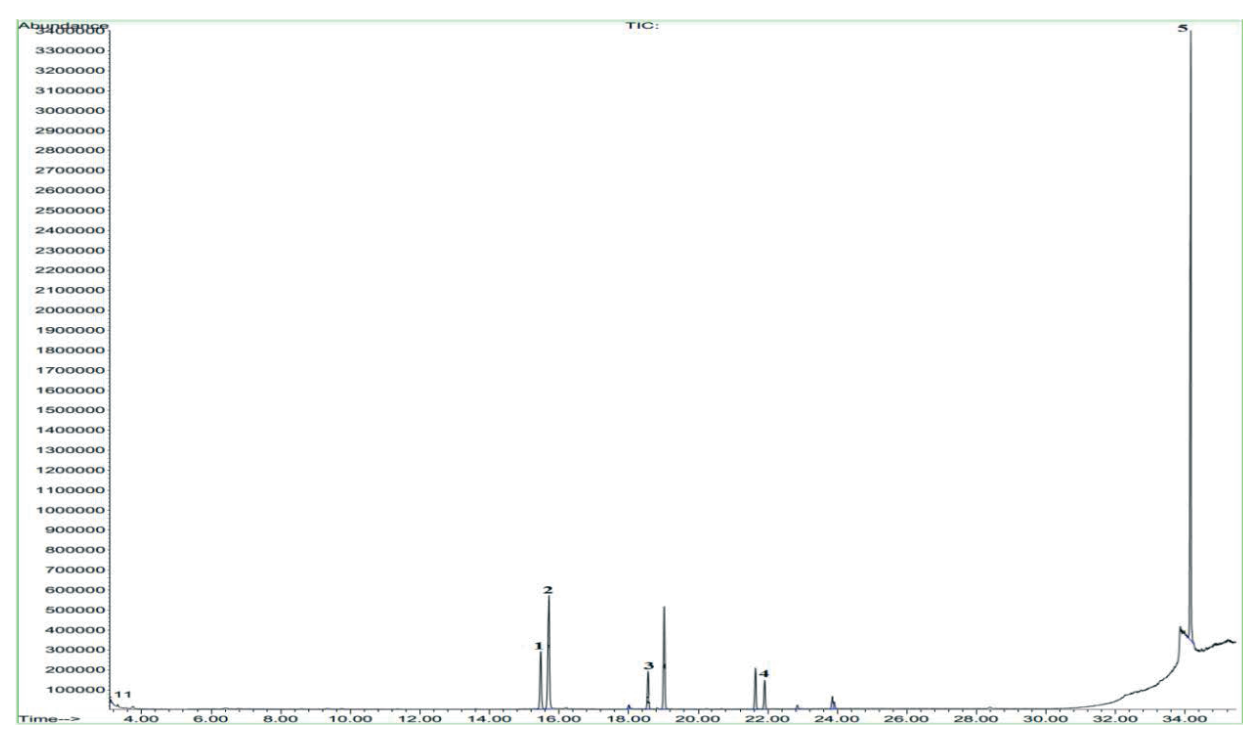

Рис. 4. Хроматограма вільних моноцукрів і сахарози трави родовика: 1 - маноза; 2 - глюкоза; 3 - інозитол; 4 - фрруктоза; 5 - сахароза. 
Серед моноцукрів у досліджуваній сировині домінувала глюкоза, яка утворилася після кислотного гідролізу, найвищий її вміст спостерігали у траві родовика $(29,96$ мг/г). Глюкози у вільному стані більше в кореневищах і коренях рослини (18,55 мг/г). Вміст сахарози в досліджуваних об'єктах був майже однаковий і становив у кореневищах і коренях 48,23 мг/г, у траві - 49,87 мг/г.

\section{СПИСОК ЛІТЕРАТУРИ}

1. Марчишин С. М. Лікарські рослини Тернопільщини / С. М. Марчишин, Н. О. Сушко. - Тернопіль : Навчальна книга - Богдан, 2007. - С. 232-234.

2. Хозяинова Н. В. Морфолого-биологические особенности Sanguisorba officinalis L. (Rosaceae) авторефр. дисс. на соискание учен. степени канд. биол. наук / Н. В. Хозяинова. - М., 1989. - 18 с.

3. Курта С. А. Природні вуглеводи та полісахариди : навч. посіб. / С. А. Курта. - Івано-Франківськ, 2013. - $100 \mathrm{c}$.

4. Солодовниченко Н. М. Лікарська рослинна сировина та фрітопрепарати : посіб. з фармакогнозії з основами біохімії лікарських рослин / Н. М. Солодовниченко, М. С. Журавльов, В. М. Ковальов. - Харків : Вид-во НФАУ : Золоті сторінки, 2001. - 408 с.

5. Кацуба І. К. Дослідження полісахаридів мати-й-мачухи / І. К. Кацуба, О. М. Новосел, В.С.Кисличенко // Укр. мед. альм. - 2013. - 16, № 4. - С. 25-27.
ВИСНОВКИ. Аналіз результатів проведених досліджень свідчить про високий вміст водорозчинних полісахаридів у кореневищах і коренях та пектинових речовин у траві родовика лікарського. Склад цукрів кореневищ і коренів, а також трави рослини характеризується переважанням у кількісному співвідношенні моноцукру глюкози та дицукру сахарози. Досліджуваний вид є перспективним для використання в медичній практиці й вимагає розширеного фрітохімічного і фрармакологічного аналізу.

6. Кисличенко В. С. Полисахариды Brassica oleacea var. Italica plenck / В. С. Кисличенко, И. Н. Владимирова // Химия природных соединений. - 2008. № 1. - С. 61-62.

7. Monosaccharide composition of Herniaria glabra L. and Herniaria polygama J.Gay / S. Kozachok, S. Marchyshyn, A. Ostapchuk, L. Zavyalova // Current Issues in Pharmacy and Medical Sciences.-2016. -29, No. 3. - P. 142-144.

8. Chen Y. Analysis of the monosaccharide composition of purified polysaccharides in Ganoderma atrum by capillary gas chromatography / Y. Chen, M. Y. Xie, Y. X. Wang [et al.] // Phytochem. Anal. - 2009. - 20 (6). P. 503-510.

9. Марчишин С. М. Визначення вмісту вуглеводів у зборі антиалергійному / С. М. Марчишин, С. С. Козачок // Фармац. журн. - 2013. - № 3. - С. 78-82.

\section{REFERENCES}

1. Marchyshyn, S.M., \& Sushko, N.O. (2007). Likarski roslyny Ternopilshchyny [Medicinal plants of Ternopil region]. Ternopil: Navchalna knyha - Bohdan [in Ukrainian].

2. Khoziaynova, N.V. (1989). Morfologo-biologicheskie osobennosti Sanguisorba officinalis L. (Rosaceae) [Morphological and biological features of Sanguisorba officinalis L. (Rosaceae)]. Extended abstract of Candidate's thesis. Moscow [in Russian].

3. Kurta, S.A. (2013). Pryrodni vuhlevody ta polisakharydy [Natural carbohydrates and polysaccharides]. Ivano-Frankivsk [in Ukrainian].

4. Solodovnychenko, N.M., Zhuravlov, M.S., \& Kovalov V.M. (2001). Likarska roslynna syrovyna ta fitopreparaty. Posibnyk z farmakohnozii z osnovamy biokhimii likarskykh roslyn [Medicinal plant material and phytomedicines. Manual on pharmacognosy with plant biochemistry]. Kharkiv: Vyd-vo NFAU: Zoloti storinky [in Ukrainian].

5. Katsuba, I.K., Novosel, O.M., \& Kyslychenko, V.S. (2013). Doslidzhennia polisakharydiv maty-y-machukhy [Research of polysaccharides from coltsfoot]. Ukrainskyi medychnyi almanakh - Ukrainian Medical Almanac, 16 (4), 25-27 [in Ukrainian].

6. Kislichenko, V.S., \& Vladimirova, I.N. (2008). Polisakharidy Brassica oleacea var. Italica plenck [Polysaccharides of Brassica oleacea var. Italica plenck]. Khimiya prirodnykh soyedineniy - Chemistry of Natural Compounds, 1, 61-62 [in Ukrainian].

7. Kozachok, S., Marchyshyn, S., Ostapchuk, A., Zavyalova, L. (2016). Monosaccharide composition of Herniaria glabra L. and Herniaria polygama J.Gay. Current Issues in Pharmacy and Medical Sciences, 29, (3), 142-144.

8. Chen, Y., Xie, M.Y., Wang, Y.X., Nie, S.P., \& Li, C. (2009). Analysis of the monosaccharide composition of purified polysaccharides in Ganoderma atrum by capillary gas chromatography. Phytochem. Anal. 20 (6), 503-510.

9. Marchyshyn, S.M., \& Kozachok, S.S. (2013). Vyznachennia vmistu vuhlevodiv u zbori antyalerhiinomu [Determination of carbohydrates content in anti-allergic composition]. Farmatsevtychnyi zhurnal - Pharmaceutical Journal, 3, 78-82 [in Ukrainian]. 


\section{ИССЛЕДОВАНИЕ УГЛЕВОДОВ КОРНЕВИЩ И КОРНЕЙ И ТРАВЫ КРОВОХЛЕБКИ ЛЕКАРСТВЕННОЙ (SANGUISORBA OFFICINALIS L.)}

\section{Резюме}

Вступление. Кровохлебка лекарственная (Sanguisorba officinalis L.) - многолетнее растение семейства розовые (Rosaceae). Для медицинских целей используют траву, которую заготавливают во время цветения, корневища и корни, которые заготавливают осенью, когда надземная часть начинает увядать. Кровохлебку лекарственную издавна применяют в народной медицине как вяжущее, противовоспалительное, болеутоляющее и кровоостанавливающее средство. Целесообразны исследования количественного содержания и качественного состава углеводов корневищ и корней кровохлебки лекарственной и ее травы, поскольку углеводы, кроме важного фрункционального значения и специфической фрармакологической активности, влияют на развитие суммарного фрармакологического эфрфекта препаратов, полученных из растительного сырья.

Цель исследования - определить, выделить и изучить полисахариды подземных органов и травы кровохлебки лекарственной, а также проанализировать их моносахаридный состав.

Методы исследования. Объектами для исследований были корневища и корни, трава кровохлебки лекарственной, заготовленные в 2014-2016 г2. на опытных участках УОК “Червона калина" Тернопольского государственного медицинского университета имени И. Я. Горбачевского (с. Дружба Тернопольского района). Для проведения качественных реакций на полисахариды готовили водные вытяжки из лекарственного растительного сырья. Количественное содержание водорастворимых полисахаридов и пектиновых веществ в исследуемом сырье определяли гравиметрическим методом. Качественный состав и количественное содержание моносахаридов и сахарозы исследовали методом газовой хромато-масс-спектрометрии.

Результаты и обсуждение. Результаты исследований подтвердили наличие полисахаридов в водных вытяжках из травы и подземных органов кровохлебки лекарственной. Установлено, что в траве растения высокое содержание пектиновых веществ (8,75 \%), в корневищах и корнях - водорастворимых полисахаридов (7,35%). В составе полисахаридных комплексов корневищ и корней кровохлебки лекарственной установлено наличие и определено количественное содержание 15 моносахаридов после кислотного гидролиза, из них идентифицировано 8; свободных сахаров выявлено 16, идентифрицировано 7 компонентов - арабинозу, маннозу, глюкозу, фрруктозу, инозитол, маннитол и дисахар сахарозу. В составе полисахаридных комплексов травы растения установлено наличие и определено количественное содержание 16 моносахаридов после кислотного гидролиза, из них идентифицировано 9; свободных сахаров выявлено 12, идентифрицировано 5 компонентов - маннозу, глюкозу, фрруктозу, инозитол и дисахар сахарозу. Среди моносахаридов в исследуемом сырье доминировала глюкоза, которая образовалась после кислотного гидролиза, высокое ее содержание наблюдали в траве кровохлебки (29,96 мг/2). Глюкозы в свободном состоянии больще в корневищах и корнях растения (18,55 мг/2). Содержание сахарозы в исследуемых объектах было почти одинаковое и составляло в корневищах и корнях 48,23 мг/2, в траве 49,87 Mг/2.

Выводы. Анализ результатов проведенных исследований свидетельствует о высоком содержании водорастворимых полисахаридов в корневищах и корнях, пектиновых веществ в траве кровохлебки лекарственной. Состав сахаров корневищ и корней, а также травы растения характеризуется преобладанием в количественном соотношении моносахарида глюкозы и дисахарида сахарозы. Исследуемый вид является перспективным для использования в медицинской практике и требует расширенного фритохимического и фрармакологического анализа.

КЛЮЧЕВЫЕ СЛОВА: кровохлебка лекарственная; трава; корневища и корни; полисахариды; саxapa. 
S. M. Marchyshyn ${ }^{1}$, V. V. Kudria ${ }^{2}$, I. S. Dakhym ${ }^{1}$, O. V. Zarichanska ${ }^{2}$ I. HORBACHEVSKY TERNOPIL STATE MEDICAL UNIVERSITY ${ }^{1}$ M. PYROHOV VINNYTSIA NATIONAL MEDICAL UNIVERSITY²

\title{
RESEARCH OF CARBOHYDRATES FROM GREAT BURNET (SANGUISORBA OFFICINALIS L.) RHIZOMES WITH ROOTS AND HERB
}

\begin{abstract}
Summary
Introduction. Great burnet (Sanguisorba officinalis L.) - is a perennial plant in the rose family (Rosaceae). Herb, collected during flowering period, and rhizomes with roots, collected in autumn when the above-ground part begins to fade, are used with medical purposes. Great burnet has been used in folk medicine for a long time as astringent, anti-inflammatory, pain-relieving and hemostatic agent. It is reasonable to study qualitative and quantitative content of carbohydrates from great burnet rhizomes with roots and herb since carbohydrates, in addition to the important functional significance and specific pharmacological activity, affect the development of the total pharmacological effect of drugs.

The aim of the study - to determine, extract and study the polysaccharides of the underground organs and the herb of great burnet, as well as analysis of their monosaccharide composition.

Research Methods. Objects of the analysis were great burnet rhizomes with roots and herb collected on research plots of academic and recreation centre "Chervona Kalyna" of I. Horbachevsky Ternopil State Medical University, (Druzhba village, Ternopil region). For the identification of polysaccharides water extracts were prepared. Quantitative content of water-soluble polysaccharides and pectin substances was determined using gravimetric method. Determination of the presence and content of monosaccharides and sucrose was conducted by gas chromatography coupled to mass-spectrometry.

Results and Discussion. The results of the studies confirmed the presence of polysaccharides in aqueous extracts from the herb and underground organs of the great burnet. It was set that in the great burnet herb the content of pectin substances was higher (8.75\%); and in rhizomes and roots - the higher content was for water soluble polysaccharides (7.35\%). In the composition of the polysaccharide complexes of rhizomes and roots of great burnet the presence and content of 15 monosaccharides after acid hydrolysis was set and 8 were identified; 7 components out of 16 free sugars were identified - arabinose, mannose, glucose, fructose, inositol and mannitol and disaccharide - sucrose. In the composition of the polysaccharide complexes of the great burnet herb the presence and content of 16 monosaccharides after acid hydrolysis was set and 9 were identified; 5 components out of 12 free sugars were identified - mannose, glucose, fructose, inositol and disaccharide - sucrose. Among the monosaccharides in the analyzed objects glucose formed after acid hydrolysis dominates, the highest content was observed in the herb $29.96 \mathrm{mg} / \mathrm{g}$. The maximum content of free glucose was in the great burnet rhizomes and roots (18.55 mg/g). Content of sucrose in both investigated objects was almost identical $(48.23 \mathrm{mg} / \mathrm{g}$ in the rhizomes and roots, and $49.87 \mathrm{mg} / \mathrm{g}$ in the herb).

Conclusions. An analysis of the results of the research shows high content of water-soluble polysaccharides in S. officinalis rhizomes and roots and pectin substances in S. officinalis herb. The composition of sugars in investigated objects is characterized by the predominance in the quantitative ratio of monosaccharide glucose and disaccharide sucrose. The investigated plant is promising for use in medical practice and requires an extended phytochemical and pharmacological analysis.
\end{abstract} sugars.

KEY WORDS: great burnet (Sanguisorba officinalis L.); herb; rhizomes and roots; polysaccharides;

Адреса для листування: С. М. Марчишин, Тернопільський державний медичний університет імені І. Я. Горбачевського, майдан Волі, 1, Тернопіль, 46001, Україна, e-mail: marchyshyn@tdmu.edu.ua. 